\title{
Геохимические особенности раннепротерозойских полифазных интрузий габброидов Северного Приладожья (ЮВ Фенноскандинавского щита)
}

\author{
Кириллова П.А. ${ }^{1,2}$, Анисимов Р.Л. 1, Галанкина О.Л. 1, Балтыбаев Ш.К. 1,2 \\ ${ }^{1}$ Институт геологии и геохронологии докембрия РАН, Санкт-Петербург, polinageo94@gmail.com \\ ${ }_{2}^{2}$ Санкт-Петербургский государственный университет, Санкт-Петербург, polinageo94@gmail.com
}

Аннотация. Ранее опубликованные результаты и полученные новые данные подтверждают полифазность формирования массивов раннеорогенных габброидов Северного домена Приладожья. Эволюция составов пород от ранних фаз к поздним в изученных массивах представляет гомодромный ряд. Геохимические особенности пород поздней фазы внедрения позволяют предполагать для нее источник магмы, отличный от источника магм ранних фаз.

Ключевые слова: габбро, РЗЭ, интрузия, источник, геохимия.

\section{Geochemical features of the Early-Proterozoic polyphase gabbroic intrusions of the Norther Ladoga area (SE of the Fennoscandian Shield)}

\author{
Kirillova P.A. ${ }^{1,2}$, Anisimov R.L. ${ }^{1}$, Galankina O.L. ${ }^{1}$, Baltybaev S.K. ${ }^{1,2}$ \\ ${ }^{1}$ Institute of Precambrian geology and geochronology RAS, St.-Petersburg, Russia, polinageo94@gmail.com \\ ${ }^{2}$ Saint-Petersburg State University,St.-Petersburg, Russia,polinageo94@gmail.com
}

\begin{abstract}
Previously published results and new data confirm of the polyphase formation of early orogenic gabbro intrusions of the Northern Domain in the Ladoga area. The evolution of the rock compositions shows the trend from a mafic to a granitic side. The rocks of the late phase of the intrusion have specific geochemical features and allow us suggest a different magma source than the magma source for the early phases.
\end{abstract}

Key words: gabbro, REE, intrusion, source, geochemistry.

\section{Введение}

Изученные магматические породы находятся на территории Северного Приладожья, где облик геологического строения определяется сочленением докембрийских мегаблоков: 1) архейского Карельского кратона, 2) протерозойского - юго-восточного фрагмента Свекофеннского пояса. Эта область известна как Раахе-Ладожская шовная зона, имеющая важное металлогеническое значение (Simonen et al., 1980).

По ряду признаков шовную зону интерпретировали как систему надвигов (Балтыбаев и др., 1996). При тектоническом районирования территории были выделены два домена: 1) Северный, приуроченый к архейской перикратонной зоне, 2) Южный - относящийся к Свекофеннскому поясу (Балтыбаев и др., 2009).

Рассматриваемые интрузивные комплексы - кааламский и велимякский - находятся в пределах Северного домена. Основу этих комплексов составляют раннеорогенные интрузии габброидов нескольких фаз внедрения. U-Pb данные не выявили значимых различий в возрасте пород разных фаз - все они образовались около 1.89 млрд лет назад (Богачев и др., 1999; Алексеев, 2008).

\section{Строение и состав интрузий}

Кааламо. К кааламскому клинопироксенит-габбронорит-диоритовый комплексу относят непосредственно сам одноименный массив Кааламо, площадью $>80$ км $^{2}$ и сопровождающие его небольшие сателлиты (до первых км²), а также мелкие тела к западу от массива. В плане Кааламский массив имеет форму овала 12.5 на 6.5 км северо-восточного простирания (рис. 1). Подошва интрузива располагается на глубинах от 2.5 км в западной его части и до 5 км в восточной (Иващенко, Голубев, 2011). Вмещают интрузию метатурбидиты и сланцы ладожской серии, а также амфиболиты сортавальской серии. Контакты массива с боковыми породами секущие, иногда субсогласные. 

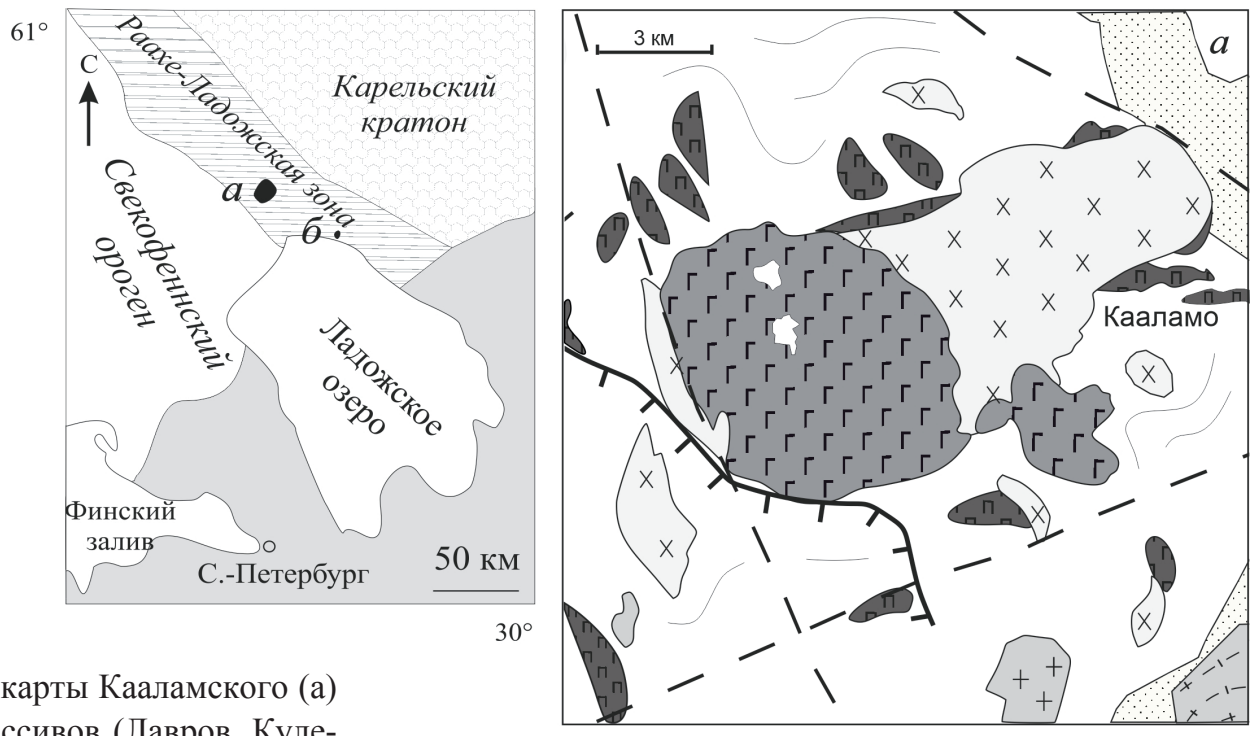

Рис. 1. Схематические карты Кааламского (а) и Велимякского (б) массивов (Лавров, Кулешевич, 2016; Балтыбаев и др., 2017) с дополнениями.

1 - пироксениты, 2 - габбро, габбро-нориты, 3 - диориты, габбро-диориты, 4 - граниты, 5 - рудные тела, 6 - породы сортавальской серии, 7 - породы ладожской серии, 8 - разломы: а - видимые, б - предполагаемые.

Fig. 1. Schematized geological maps of the Kaalamo (a) and Velimyaky (б) massifs (Lavrov, Kuleshevich, 2016; Baltybaev et al., 2017), as supplemented.

1 - pyroxenites, 2 - gabbro, gabbro-norites, 3 - diorites, gabbro-diorites, 4 - granites, 5 - ore bodies, 6 - rocks of the Sortavala series, 7 - rocks of the Ladoga series, 8 - faults: a - visible, 6 - proposed.
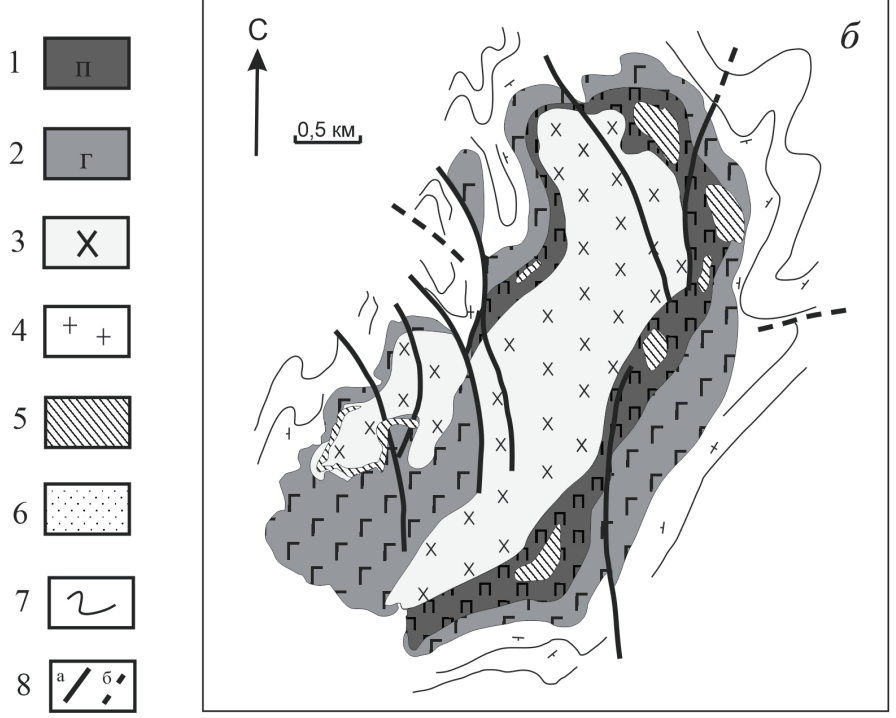

В интрузии есть ксенолиты вмещающих пород. Это разного размера слюдяные гнейсы и сланцы, амфиболовые породы, карбонаты (Саранчина, 1949). Породы кааламского комплекса метаморфизованы совместно с вмещающими породами в условиях от верхов зеленосланцевой до амфиболитовой фаций.

Большинство исследователей выделяют три группы пород, соотносящиеся как интрузивные фазы гомодромной последовательности. К первой фазе относят верлиты, оливиновые клинопироксениты, плагиопироксениты и меланократовые габбро; вторая фаза представлена габброноритами, габбро, меланодиоритами; третья фаза характеризуется более кислыми разностями: диоритами, кварцевыми диоритами, гранодиоритами, тоналитами, плагиогранитами (Иващенко, 2020). С первой фазой связано медно-никелевое оруденение. Составы пород Кааламского массива варьируют от габбро до гранодиоритов (рис. 2a). На AFM диаграмме эти породы образуют переходный тренд от толеитового ряда к известково-щелочному с ростом кремнекислоты (рис. 2 б).

Велимяки. Велимякский интрузивный комплекс объединяет собственно массив Велимяки (рис. 1) и интрузивные породы о. Мякисало (Алексеев, 2008). Этот пироксенит-габбро(монцо)диоритовый комплекс исследователями причисляется к кааламской группе интрузивов, хотя данный массив отличается большим разнообразием пород с щелочными составами, наличием титаномагнетитовых и сульфидных руд разной генерации и возраста (Балтыбаев и др., 2017). Велимякский мас- 

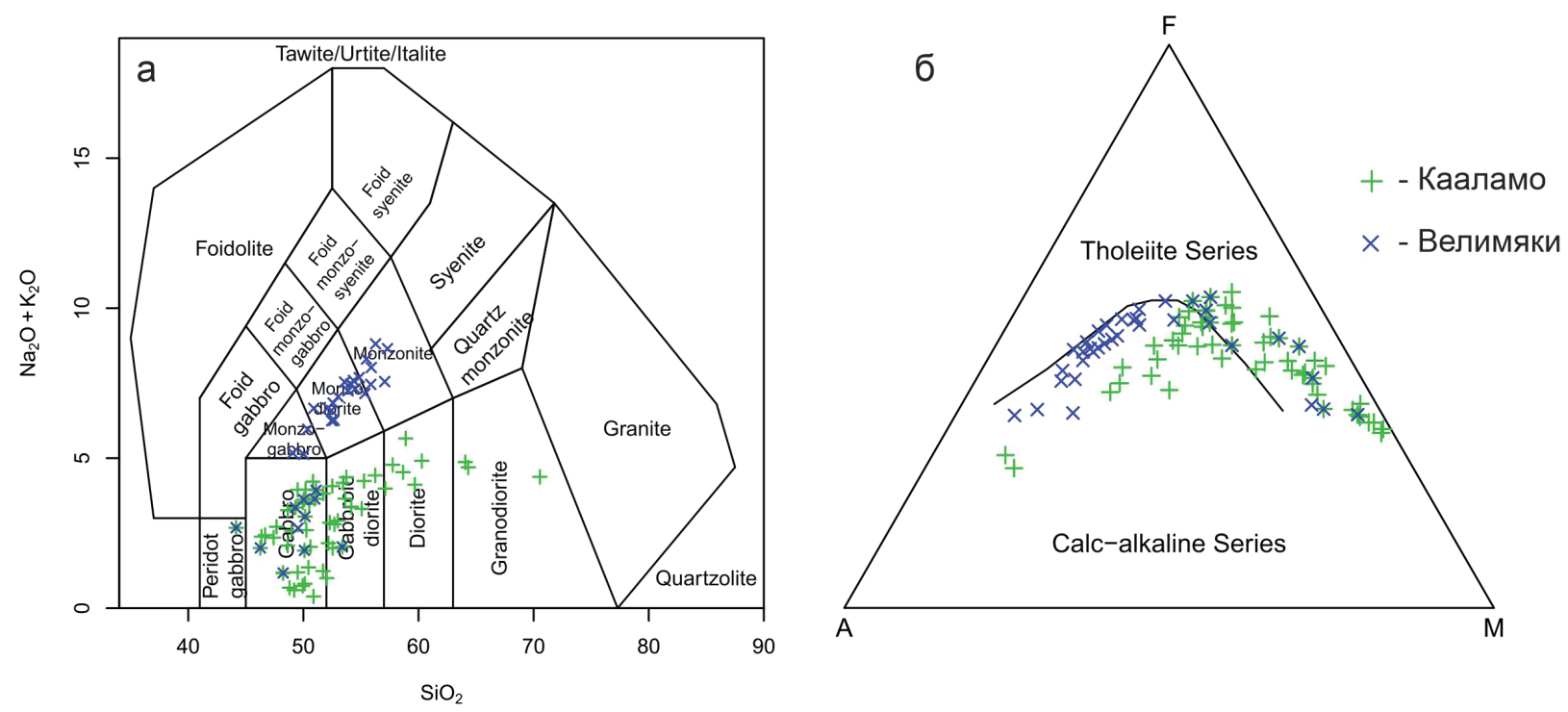

Рис. 2. Классификационные диаграммы для пород кааламского и велимякского комплексов: a - TAS (Middlemost, 1994), б - AFM (Irvin, Baragar, 1971). Авторские и опубликованные данные (Свириденко и др., 1976; Богачев и др., 1999; Алексеев, Котова, 2010; Иващенко, Голубев, 2011; Лавров, Кулешевич, 2016; Алексеев, Кулешевич, 2017).

Fig. 2. Classification diagrams for the Kaalamo and Velimyaky complexes: a - TAS (Middlemost, 1994), б - AFM (Irvin, Baragar, 1971). The author's and published data were used (Sviridenko et al., 1976; Bogachev et al., 1999; Alekseev, Kotova, 2010; Ivashchenko, Golubev, 2011; Lavrov, Kuleshevich, 2016; Alekseev, Kuleshevich, 2017).

сив дифференцирован от перидотитов и пироксенитов до габбро и диоритов (Алексеев, 2008). Площадь его $\sim 10$ км $^{2}$, имеет овальную форму $3.5 \times 2$ км. Интрузия прорывает сланцы ладожской серии.

Г.М. Саранчина предполагает последовательность образования пород: перидотиты и пироксениты, габбро-диориты, мангериты и жильные породы сиенитового ряда. Центральную, северную и северо-восточную часть массива слагают метаморфизованные габбро-диориты (Саранчина, 1948). Некоторые исследователи выделяют еще приконтактовые диориты в виде маломощной каймы вдоль западного контакта массива и небольшие оторочки вдоль восточного контакта (Алексеев, Кулешевич, 2017).

Мелкие тела пироксенитов наблюдаются повсеместно. Они чаще амфиболизированы (до амфиболитов). Пироксениты и перидотиты к периферии массива образуют более крупные тела, где к ним приурочены месторождения титаномагнетита.

Мангериты и жильные породы сиенитового ряда распространены в южной части массива. Их магматический генезис оспаривается (Алексеев, Кулешевич 2017), полагая более позднее (постмагматическое) происхождение калиевого полевого шпата.

Составы пород Велимякского массива меняются от габбро и частично перидотитов до монцогаббро и монцонитов (рис. 2 a). На AFM диаграмме породы образуют тренд от толеитового ряда к известково-щелочному с ростом кремнезема (рис. 2 б).

\section{Петрографическая характеристика основных типов пород изученных массивов}

Пироксениты - темно-серого цвета, неравномернозернистые (мелко-крупнозернистые), массивные. Местами полностью преобразованы в амфиболиты, структуру можно описать как нематобластовую, также встречаются более мелкозернистые участки с гранобластовой структурой. Минеральный состав: амфибол (80-95\%), плагиоклаз (до 10\%), может наблюдаться также биотит и хлорит (до 10\%), карбонат (до 10\%), рудный минерал (до $5 \%$ ). Кроме того, в породе может отмечаться незначительное количество эпидота, титанита, граната (до 1-2\%). 

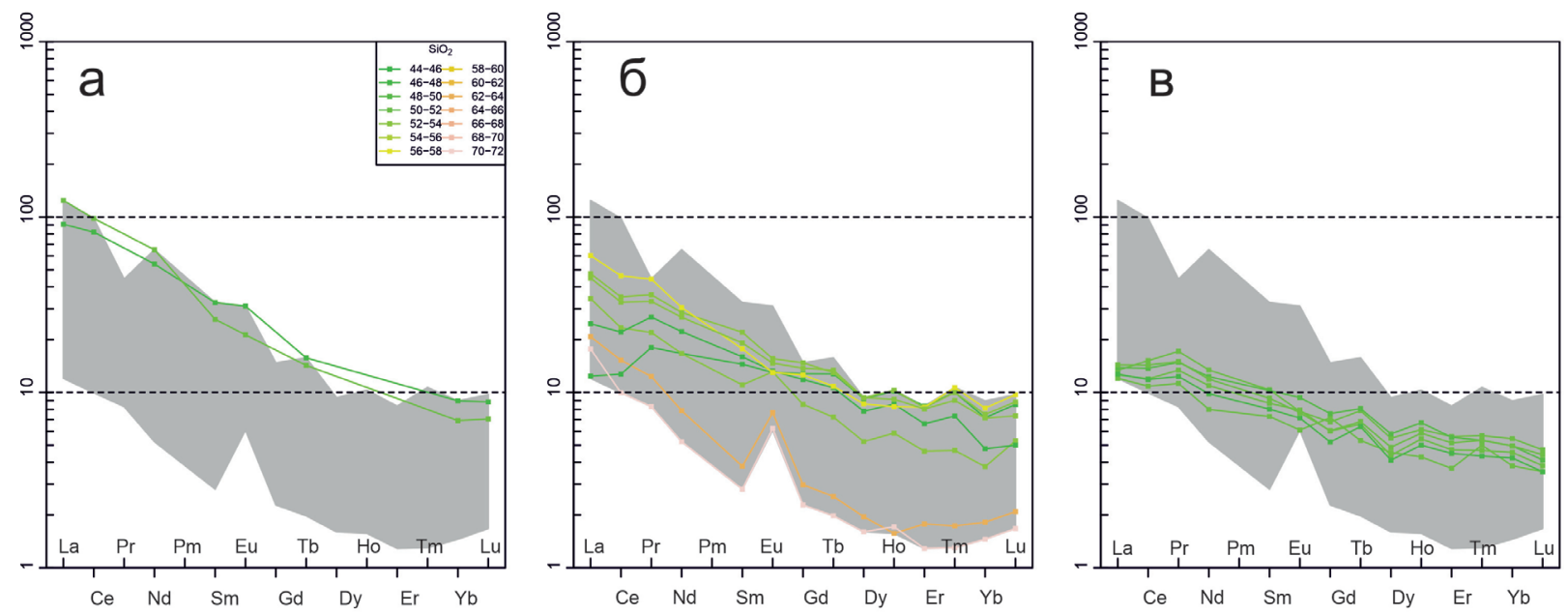

Рис. 3. Спайдер-диаграммы для кааламского и велимякского комплексов (опубликованные и авторские материалы). Нормирование по хондриту (Nakamura, 1974). Серым цветом показано РЗЭ для всех 16 образцов: из велимякского (2 обр., рис. 3 а) и кааламского (14 обр., рис. 3 а, б). Авторские данные показаны на рис. 3 б, где отчетливо видна группа пород с положительной Еu аномалией.

Fig. 3. Spider diagrams for the kaalamo and velimyaky complexes (published and author's data, normalaized to chondrite (Nakamura, 1974)). The gray field shows the REE distribution for all 16 samples from the Velimyaky (2 samples, Fig. 3 a) and Kaalamo (14 samples, Fig. 3 a, б) complexes. The author's data are shown in Fig. 36 , where a group of rocks with a positive Eu anomaly is clearly visible.

В Велимякской интрузии пироксениты представлены крупными телами линзовидной и овальной формы, а также, в виде шлировидных, жилоподобных разностей. Вмещающими породами для них являются габбро и диориты. По содержанию породообразущих и второстепенных минералов выделены: плагиоклазсодержащие, биотитовые, роговообманковые и рудные магнетитовые пироксениты.

Габбронориты, габбродиориты - среднезернистые, массивные породы. Их цвет изменяется от темно-серого до беловато-серого (в зависимости от содержания плагиоклаза). Микроскопическая структура может быть описана как офитовая с элементами пойкилитовой, однако в породе отмечаются как первичные минералы (ромбический и моноклинный пироксены), так и замещающие их метаморфические минералы (амфибол, биотит). Минеральный состав: плагиоклаз (50-70\%), ромбический пироксен (до $20 \%$ ), моноклинный пироксен (до $5 \%$ ), амфибол (до $30 \%$ ), биотит (до $10 \%$ ). Согласно литературным данным плагиоклаза от 22 да 82\%, амфибола от 3 до 70 \% (Свириденко и др., 1976). Второстепенные и акцессорные минералы: калиевый полевой шпат, магнетит, апатит; по литературным данным также куммингтонит, минералы эпидот-цоизитового ряда (Свириденко и др., 1976).

Диориты - средне-мелкозернистые породы, внешне очень схожи с габбро. Содержат примерно до $50 \%$ плагиоклаза. Темноцветы представлены амфиболом (до $25 \%$ ) клинопироксеном (до $15 \%$ ), биотитом (до $10 \%$ ).

Тоналиты представляют собой породы беловато-серого цвета, мелко-среднезернистые, массивные или неявно директивные. Структура лепидогранобластовая, со следами резорбции. Породы сложены плагиоклазом (55-60\%), кварцем (15-30\%), биотитом (10-15\%), амфиболом (3-15\%). Акцессорные и второстепенные минералы представлены калиевым полевым шпатом, цирконом, апатитом, минералами эпидот-цоизитового ряда.

Данные о распределении РЗЭ в породах комплексов были немногочисленны, поэтому представлялось, что содержание РЗЭ у пород примерно одинаковое, а их распределение указывает на относительно слабое фракционирование редких земель. Новые данные позволили выявить группу пород поздней фазы внедрения (диориты, гранодиориты, тоналиты) со своей спецификой (рис. 3). Они, во-первых, с резко выраженной положительной Еu аномалией, во-вторых, при суммарно низ- 
ком содержании РЗЭ, фракционированы сильнее. Положительная Еu аномалия контролируется содержанием плагиоклаза в породе. В совокупности с данными изотопного состава свинца (авторские неопубликованные данные), выявленный спектр РЗЭ отражает, по нашему мнению, иной источник магмы у поздних фаз интрузий Кааламо и Велимяки.

\section{Выводы}

Ранее опубликованные результаты и полученные новые данные подтверждают полифазность формирования массивов раннеорогенных габброидов Северного домена Приладожья. Эволюция составов пород от ранних фаз к поздним в изученных массивах представляет гомодромный ряд. Геохимические особенности пород поздней фазы внедрения позволяют предполагать для нее источник магмы, отличный от источника магмы ранних фаз.

Работа выполнена в рамках темы НИР №0132-2019-00013.

\section{Литература}

1. Алексеев И.А. Геология и рудоносность массива Вялимяки (Северное Приладожье). Дис. канд. ... геол.-минер. наук. СПб. 2008. 184 с.

2. Алексеев И.А., Кулешевич Л.В. Благороднометалльная минерализация массива Вялимяки (Северное Приладожье, Карелия) // Тр. КарНЦ РАН. 2017. Сер. Геология докембрия. № 2. С. 60-72. DOI: $10.17076 /$ geo115.

3. Балтыбаев Ш.К., Глебовицкий В.А., Козырева И.В., Шульдинер В.И. Мейерский надвиг - структура сочленения Карельского кратона и Свекофеннского пояса в Приладожье // Докл. РАН. 1996. Т. 348. № 3. С. 353-356.

4. Балтыбаев Ш.К., Левченков О.А., Левский Л.К. Свекофеннский пояс Фенноскандии: пространственновременная корреляция раннепротерозойских эндогенных процессов. СПб.: Наука. 2009. 328 с.

5. Балтыбаев Ш.К., Овчинникова Г.В., Глебовицкий В.А., Алексеев И.А., Васильева И.М., Ризванова Н.Г. Каледонское время образования золотосодержащих сульфидных руд в раннепротерозойских габброидах Северного Приладожья // Докл. АН. 2017. Т. 476. № 2. С. 181-185. DOI: 10.7868/S0869565217260139.

6. Богачев В.А., Иваников В.В., Козырева И.В. и др. U-Рb цирконовое датирование синорогенных габбродиоритовых и гранитоидных интрузий Северного Приладожья // Вестн. СПбГУ. 1999. Вып. 3. С. $23-33$.

7. Иващенко В.И., Голубев А.И. Золото и платина Карелии: Формационно-генетические типы оруденения и перспективы. Петрозаводск. Изд-во: Карельский научный центр РАН. 2011. 369 с.

8. Иващенко В.И. Кааламский комплекс // Ладожская протерозойская структура (геология, глубинное строение и минерагения) (отв. ред. Н.В. Шаров). Петрозаводск. Изд-во: КарНЦ РАН. 2020. С. 76-85.

9. Лавров О.Б., Кулешевич Л.В. Перспективы поисков платиноидов в массивах Кааламского дифференцированного комплекса (Северное Приладожье, Карелия) // Отечественная геология. 2016. №3. С. 46-56.

10. Саранчина Г.М. Петрология Вялимякской интрузии и связанное с нею рудопроявление // Изв. КарелоФинск. науч.-исслед. базы АН СССР. 1948. № 2. С. 32-42.

11. Саранчина Г.М. Петрология Калаамской интрузии (юго-западная Карелия) // Изв. Карело-Финск. науч.исслед. базы АН СССР. 1949. № 2. С. 57-80.

12. Свириденко Л.П., Семенов А.С., Никольская Л.Д. // Интрузивные базит-ультрабазитовые комплексы докембрия Карелии. Л. Изд-во: Наука.1976. 165 с.

13. Irvine T.N., Baragar W.R.A. A guide to the chemical classification of the common volcanic rocks. Canadian Journal of Earth Sciences. 1971. V. 8. P. 523-548.

14. Middlemost E.A.K. Naming Materials in the Magma/Igneous Rock System. Earth-Science Reviews. 1994. V. 37. P. 215- 244. DOI: 10.1016/0012-8252(94)90029-9.

15. Nakamura N. Determination of REE, Ba, Fe, $\mathrm{Mg}, \mathrm{Na}$ and $\mathrm{K}$ in Carbonaceous and Ordinary Chondrites. Geochimica et Cosmochimica Acta. 1974. V. 38. P. 757-775. http://dx.doi.org/10.1016/0016-7037 (74)90149-5.

16. Simonen A. The Precambrian in Finland // Geol. Surv. Finland Bull. 1980. № 304. 58 p. 